\title{
HAK WARIS ANAK LAKI-LAKI TERTUA DALAM HUKUM ADAT LAMPUNG PEPADUN PERSPEKTIF GENDER (STUDi Di TEGINENENG KabUPATEN PESAWARAN)
}

\author{
Habib Ismail \\ LAIMNU Metro Lampung, babibismail65@gmail.com \\ Hasyim Asyári \\ IAIMNU Metro Lampung, basyimasari694@gmail.com \\ Agus Setiawan \\ IAIMNU Metro Lampung, agussetiawanrini@gmail.com
}

\begin{abstract}
The existing Lampung Indigenous Peoples Pepadun in Tigeneneng sub-district, Kab. Pesawaran, adheres to a patrilneal kinship system. This means that the oldest son is an absolute heir in the implementation and management of inheritance with the bighest customary title, namely balancing. Whereas for the female heirs, they were not given the right of authority in management, because in the adat of Lampung Province the daughters were considered unable to manage inheritance and daughters when they were married, so they would change their customary titles and would follow their husbands. This type of research is a field using a qualitative approach by analyzing data inductively. The result of this research is that the system applied in the distribution of inheritance rights to the eldest child in the Lampung tribal community, is clearly very contrary to the principle of gender equality and justice. Juridically normative equality and gender justice have been regulated in Islamic Law and International Convention (CEDAW). Even though juridically, girls have the same rights as boys in managing inheritance left by both parents.
\end{abstract}

Keyword:Inheritance Rights of Terua Boys, Traditional Lampug Pepadun, Gender.

\begin{abstract}
Abstrak
Masyarakat Adat Lampung Pepadun yang ada dikecamatan Tigeneneng, Kab. Pesawaran, menganut sistem kekerabatan patrilneal. Artinya anak laki-laki tertua adalah abli waris mutlak dalam pelaksanaan dan pengelolaan pewarisan dengan gelar adat yang tertinggi yaitu penyeimbang. Sedangkan untuk abli waris dari pibak perempuann tidak diberikan hak kuasa dalam pengelolaan, dikarenakan dalam adat lampung pepadun anak perempuan dianggap tidak mampu dalam mengelola barta warisan dan anak perempuan ketika sudah menikah, maka akan berpindah gelar adatnya dan akan mengikuti suaminya. Jenis penelitian ini adalab lapangan dengan menggunakan pendekatan kualitatif dengan analisis data secara induktif. Hasil dari penelitian ini adalah sistem yang diterapkan dalam pembagian bak waris terhadap anak tertua pada masyarakat adat lampung pepadun, jelaslah sangat bertentangan dengan prinsip keseteraan dan keadilan gender. Secara yuridis normative kesetaraan dan keadilan gender telah diatur dalam Hukum Islam dan Konvensi Internasional (CED AW). Padahal secara yuridis, anak perempuan adalah mempunyai hak yang sama dengan anak laki-laki dalam mengelola harta warisan yang telah ditinggalkan oleh kedua orang tua.
\end{abstract}

Kata Kunci: Hak Waris Anak Laki-laki Terua, Adat Lampug Pepadun, Gender.

\section{PENDAHULUAN}

Pada dasarnya syariat Islam diturunkan semata-mata demi kemaslahatan hidup umat manusia di dunia maupun di akhirat. Aturan dan hukum-hukum Ilahi, baik yang secara eksplisit tertuang dalam Alquran dan Hadis, maupun aturan hukum yang digali melalui proses kajian yang mendalam oleh para pakar dari periode ke periode, semua kembali pada tujuan bagaimana menciptakan kemaslahatan dan menghindari mafsadah yang mungkin timbul andaikan kita semua membiarkan 
manusia berjalan mengikuti kehendak hawa nafsunya.

Oleh karena itu, perlu meletakkan hak dan kepentingan manusia secara jelas, agar tercipta kemaslahatan dan menghindari kemafsadahan tersebut. ${ }^{1}$ Dari sekian banyak hak tersebut, fakta empiris menunjukan bahwa pemeliharaan harta yang dimiliki oleh manusia cenderung menimbulkan konflik di dalam masyarakat yaitu harta waris. Kewenangan tentang hak waris, seringkali menimbulkan suatu permasalahan yang genting dan rentan di dalam sebuah keharmonisan keluarga. Semua itu bermula dari ketertarikan seseorang atas harta warisan yang menjadikan pemicu perubahan sesuatu yang awalnya merupakan sebuah keberkahan, penuh dengan nilai-nilai kesosialan, kemudian menjadi pemicu permasalahan yang penuh dengan nilai negatif dan kesenjangan. ${ }^{2}$

Hal ini mencuat bukan karena tidak ada jalan atau solusi dalam menyelesaikan permasalahannya. Akan tetapi hal tersebut muncul karena didasari berbagai faktor salah satunya adalah ketidaktahuannya tentang hukum kewarisan dan juga disebabkan oleh keserakahan dan rasa egois yang tinggi, sehingga muncullah berbagai kasus yang merebak di berbagai wilayah salah satunya permasalahan mengenai hukum waris baik waris dengan tata cara Islam maupun waris yang menggunakan hukum adat.

Masyarakat hukum adat yang bersifat majemuk adalah suatu kesatuan sosial yang terdiri dari kumpulan beberapa individu, yang mana para anggotanya tersebut telah percaya dan meyakini akan suatu garis keturunan yang sama, baik disebabkan karena hubungan darah dan/atau secara melalui pertalian pernikahan ataupun pertalian adat. $^{3}$ Sifat kemajemukan

${ }^{1}$ La Jamaa, "Dimensi Ilahi dan Dimensi Insani dalam Maqashid al-Syari'ah” 45 (2011):, 1257.

${ }^{2}$ M. Syifa'uddin Achmadi, Pintar Ilmu Faraidl Piliban Tepat Meredam Sengketa Harta Waris, Cet. 1 (Surabaya: Khalista, 2006), . xvii.

${ }^{3}$ Hilman Hadikusuma, Pengantar Ilmu Hukum tersebut antara lain, yaitu; pertama, masyarakat yang bersifat patrilineal, yang kedua, masyarakat yang bersifat matrilineal, dan bersifat parental.

Pada Masyarakat Adat Lampung sendiri mempunyai beberapa budaya suku adat yang dibedakan menjadi dua kelompok adat, yaitu masyarakat adat pesisir (Adat Saibati) dan masyarakat Adat Pepadun, yang mana masyarakat adat ini mayoritas memeluk agama Islam.

Masyarakat Adat Pepadun menganut sistem kekerabatan patrilineal yang mengikuti garis keturunan bapak. Dalam suatu keluarga, kedudukan adat yang paling tinggi diberikan pada anak laki-laki tertua dari keturunan bapak yang dituakan, yang disebut "penyeimbang". Gelar penyeimbang ini sangat dihormati dalam Adat Pepadun karena menjadi penentu dalam ritual penetapan keputusan, salah satunya dalam pembagian harta warisan. Akan tetapi, dalam pengambilan keputusan tersebut tidak menguntungkan bagi pihak anak perempuan, karena dengan peraturan adat tersebut menjadikan anak tertua dalam memegang harta warisan yang telah ditingalkan oleh orang tuanya. Sehingga menjadikan keputusan tersebut menjadi konflik dan permasalahan yang berkepanjangan dalam satu keluarga terutama terhadap pihak wanita yang sampai saat ini masih belum memperoleh statusnya dalam keadilan gender.

Berdasarkan latar belakang tersebut, penulis ingin mendalami kasus ini lebih dalam mengenai makna filosofinya dalam pemberian hak atas harta warisan tersebut menurut hukum adat pepadun yang menjadi kewenangan anak tertua. Selanjutnya pembahasan akan diperkaya dengan pandangan yang berlandaskan Hukum Islam, hukum adat dan Legislasi Kewarisan. Menanggapi perihal di atas, maka penulis mengangkat judul: Hak Waris Anak Laki-Laki Tertua Dalam Hukum Adat Lampung Pepadun Perspektif Gender (Studi Di Adat Indonesia (Bandung: Mandar Maju, 1992), . 108. 
Tegineneng Kabupaten Pesarawan).

\section{KONSEP HUKUM KEWARISAN DALAM ISLAM}

Adapun yang menjadi dasar pelaksanaan pembagian harta warisan dalam hukum Islam adalah berpedoman pada Alquran dan Hadis. ${ }^{4}$ Alquran

Surat Al-Baqarah ayat 180:

"Diwajibkean atas kamu, apabila seorang di antara kamu kedatangan (tanda-tanda) maut, jika ia meninggalkan harta yang banyak, Berwasiat untuk ibu-bapak dan karib kerabatnya secara ma'ruf, (ini adalab) kewajiban atas orang-orang yang bertakwa."

Surat An-Nisa ayat 7:

"Bagi orang laki-laki ada hak bagian dari barta peninggalan ibu-bapa dan kerabatnya, dan bagi orang wanita ada hak bagian (pula) dari barta peninggalan ibu-bapa dan kerabatnya, baik sedikit atau banyak menurut bahagian yang telah ditetapkan".

Surat An-Nisa ayat 59:

"Hai orang-orang yang beriman, taatilah Allab dan taatilab Rasul (Nya), dan ulil amri di antara kamu. kemudian jika kamu berlainan Pendapat tentang sesuatu, Maka kembalikanlah ia kepada Allab (Al Quran) dan Rasul (sunnabnya), jika kamu benarbenar beriman kepada Allah dan bari kemudian. yang demikian itu lebib utama (bagimu) dan lebih baik akibatnya”.

Hadis

Hadis yang diriwayatkanAhmad. Abu Dawud, Tirmidzi, dan Ibnu Majah.

"Sesunggubnya Allab SWT., telah memberi kepada orang yang berbak atas haknya. Ketahuilab! Tidak ada wasiat kepada abli waris. (H.R. Ahmad. Abu Dawud, Tirmidzi, dan Ibnu Majah) ${ }^{6}$

4 Sakirman, "Konvergensi Pembagian Harta Waris Dalam Hukum Islam," ALHURRIY AH: Jurnal Hukum Islam 2, no. 1 (July 18, 2017): 45-56-56, doi:10.30983/alhurriyah.v2i1.261.

5Departemen Agama RI, Al-Qur'an dan Terjemahnya (Bandung: CV. J-ART, 2005), 79.

'Saebani, Fiqh Mawaris, 2009, 13.
Hadis yang di riwayatkan dari Ibn 'Abbas

"Sampaikanlah bagian-bagian pasti pada ablinya (orang-orang yang berbak. mendapatkan), sedangkah kelebihannya adalah hak abli waris laki-laki yang paling dekat nasabnya dengan muwarits (yang meninggalkan pusaka). (HR. Al-Bukhari dan Muslim) ${ }^{7}$

Hadis yang diriwayatkan oleh Ibnu Abdillah bin Muhammad bin 'Aqil, dari Hatim bin Abdullah, dan dari Jabir r.a.

"Sesungoubnya Nabi SAW memberikan kepada dua orang anak perempuan bagian dari harta warisan dua pertiga. ${ }^{8}$

\section{KONSEP HUKUM KEWARISAN ADAT MASYARAKAT LAMPUNG PEPADUN PENGERTIAN HUKUM WARIS ADAT}

Adat berasal dari bahasa Arab, dan istilah ini telah hampir menjadi bahasa disemua daerah Indonesia. Adat diartikan kebiasaan, sehingga secara sederhana hukum adat dapat diartikan kedalam bahasa Indonesia menjadi hukum kebiasaan. ' Waris adat adalah hukum kewarisan yang berlaku dikalangan masyarakat Indonesia yang tidak bersumber pada peraturan. Berdasar pada pengertian hukum adat yang dikumukakan oleh Djojodigono, yang menyatakan hukum adat adalah suatu hukum yang tidak bersumber kepada peraturan-peraturan, sebagai pengecualian hukum waris Islam yang berlaku di suatu daerah di Indoneisa meskipun tidak berdasarkan peraturan, tidak disebut hukum adat. Menurut Teer Haar menyatakan hukum waris adat yaitu aturan-aturan hukum yang mengenai cara bagaimana dari abad ke abad penerusan serta peralihan dari harta kekayaan yang berwujud dan tidak berwujud dari

${ }^{7}$ M. Syifa'uddin, Pintar Ilmu Faraidl Pilihan Tepat Meredam Sengketa Harta Waris, 11.

${ }^{8}$ Rusyd, Bidayatul Mujtabid Analisis Fiqih Para Mujtabid, 384-385.

'Komari, "Eksistensi Hukum Waris Di Indonesia: Antara Adat Dan Syariat," Asy-Syariab 17, no. 2 (Agustus 2015): 158. 
generasi pada generasi. ${ }^{10}$ Hukum Adat waris adalah peraturan hukum yang mengatur proses kelanjutan dan pemindahan harta benda dan barang tak berwujud (immateriil gaederen) dari generasi manusia (generatie) ke keturunan atau ahli warisnya. ${ }^{11}$

Sedangkan menurut Wirjono Projodikoro, hukum adat pada umumnya bersandar pada kaidah sosial normatif dalam cara berfikir yang kongkret, yang sudah menjadi tradisi masyarakat diwilayah tertentu. Salah satunya masyarakat minangkabau yang membagi harta waris dengan hukum adat, yang secara subtansial sumber utama dari hukum adat itu sendiri adalah syariat islam. Oleh karena itu, ditetapkan dalam doktrin adat bersendi syara, syara bersendi kitabullah. ${ }^{12}$

Menurut Soejono Soekamto juga menyatakan bahwa hukum adat merupakan hukum kebiasaan, yang artinya kebiasaankebiasaan yang mempunyai akibat hukum dan perbuatan-perbuatan yang diulang-ulang dalam bentuk yang sama. ${ }^{13}$

Bushar Muhammad menyatakan bahwasanya hukum waris dalam hukum adat selalu dimaknai dengan serangkaian peraturan yang mengatur peralihan harta warisan atau harta peninggalan dari satu generasi ke generasi lain, baik mengenai benda material maupun immaterial. Hal ini sekaligus menunjukkan bahwa dalam proses kewarisan tidak harus berlangsung dalam suasana kematian. Hal itu berarti bahwa dalam hukum waris adat mencakup pula masalah tindakantindakan mengenai pelimpahan harta benda

${ }^{10} \mathrm{Juli}$ Astuti MR, "Kedudukan Anak Luar Kawin Dalam Pewarisan Adat Di Kecamatan Colomadu Kabupaten Karanganyar" (PhD Thesis, Universitas Diponegoro, 2004), 29.

${ }^{11}$ A Mukhlishin dkk., "Studi Hukum Islam Terhadap Kewarisan Masyarakat Adat Semendo Kabupaten Lampung Barat Di Era Kontemporer," Ulul Albab Jurnal Studi Islam 18, no. 1 (31 Juli 2017): 95, https://doi.org/10.18860/ua.v18i1.4125.

${ }^{12 B e n i}$ Ahmad Saebani, Figh Mawaris, Cet.3 (Bandung: CV. Pustaka Setia, 2015), 86.

13Soejono Soekamto, Pengantar Hukum Adat Indonesia (Jakarta: Rajawali, 1993), 37. semasa seseorang masih hidup. ${ }^{14}$

Dalam hukum kewarisan adat tidak semata-mata hanya akan menguraikan tentang warisan dan hubunganny dengan ahli waris, tetapi lebih luas dari hal tersebut. Istilah hukum kewarisan adat dalam hal ini adadalah untuk membedakan dengan istilah hukum kewarisan Barat, hukum kewarisan Islam, dan hukum kewarisan Indonesia. ${ }^{15}$

Hukum waris adat menunjukan corakcorak yang khas dari suatu pikiran tradisional bangsa Indonesia. Hal ini yang membedakannya dari hukum Islam maupun hukum perdata. Perbedaan terutama terutama terletak pada latar belakang alam pikiran bangsa Indonesia yang berfalsafah Pancasila dengan masyarakat yang ber Bhineka Tunggal Ika. Latar belakang tersebut pada dasarnya adalah kehidupan bersama yang bersifat kekeluargaan, saling tolong menolong guna mewujudkan kerukunan, keselarasan, serta kedamaian di dalam hidup. ${ }^{16}$

Pada dasarnya sistem hukum pembagian kewarisan adat sangat erat kaitannya dengan bentuk masyarakat dan sifat kekeluargaan. Sedangkan sistem kekeluargaan pada masyarakat khususnya Indonesia, berpangkal pada sistem dengan menarik garis dari keturunan. Berkaitan dengan system penarikan garis keturunan, seperti yang telah diketahui di Indonesia secara umum mengenal dengan tiga macam sistem keturunan.

\section{Sistem Patrilinial (GarisKebapakan)}

Sistem ini pada prinsipnya adalah sistem kekerabatan yang menarik dari garis keturunan

${ }^{14}$ Fikri \& Wahidin Fikri \& Wahidin, "Konsepsi Hukum Waris Islam dan Hukum Waris Adat (Analisis Kontekstualisasi dalam Masyarakat Bugis)," Al-Abkam: Jurnal Ilmu Syari'ah dan Hukum 2, no. 2 (8 Januari 2017): . 200, https://doi.org/10.22515/al-ahkam.v2i2.500.

${ }^{15}$ Hilman Hadikusuma, Hukum Waris Adat (Bandung: Citra Aditya Bakti, 1990), 8.

${ }^{16}$ Asri Thaher, "Sistem Pewarisan Kekerabatan Matrilineal Dan Perkembangannya Di Kecamatan Banuhampu Pemerintahan Kota Agam Propinsi Sumatera Barat" (PhD Thesis, Universitas Diponegoro, 2006), 13. 
ayah (patriarkhat atau patriarkhi) atau garis keturunan nenek moyangnya yang laki-laki. Sistem ini akan berpengaruh dalam hal pemberian suku atau marga untuk anak yang lahir, pengaturan hak dan kewajiban dalam adat, sistem kewarisan, dan lain-lain. Di Indonesia suku atau golongan ras yang menganut sistem kekerabatan ini antara lain pada masyarakat di Tanah Gayo, Alas, Batak, Ambon, Irian Jaya, Timor, Bali, dan Lampung.

Dalam sistem kewarisan ini kedudukan dan pengaruh pihak laki-laki sangatlah penting perannya. Karena yang menjadi ahli waris hanya dari pihak laki-laki (anak laki-laki), sebab kedudukan seorang anak perempuan yang telah kawin dengan menggunakan cara "kawin jujur" yang kemudian dimasukkan menjadi anggota keluarga dari pihak suami dan selanjutnya dengan menjadi istri tersebut ia tidak menjadi ahli waris dari orang tuanya jika meninggal dunia. ${ }^{17}$ Ahli waris dalam sistem hukum adat garis patrilineal, terdiri dari: 1) Anak laki-laki, 2) Anak angkat, 3) Ayah dan ibu serta saudara-saudara sekandung sipewaris, 4) Keluarga terdekat dalam derajat yang tidak tertentu, dan 5) Persekutuan adat maksudnya apabila para ahli waris yang telah disebutkan tidak ada, maka harta warisan akan diberikan atau jatuh kepada persekutuan adat. ${ }^{18}$

Tatacara atau sistem yang dipergunakan dalam perkawinan masyarakat adat Lampung sangat berbeda jika dibandingkan dengan perkawinan yang menggunakan sistem matrilineal (hukum adat di Minangkabau).

Berikut dapat dikemukakan sample larangan dan kebolehan perkawinan yang ada di Lampung seperti gambar berikut ini:

${ }^{17}$ Eman Suparman, Hukum Waris Indonesia dalam Perspektif Islam, Adat dan BW (Jakarta: Refika Aditama, 2005), . 43.

18Suparman, 50.

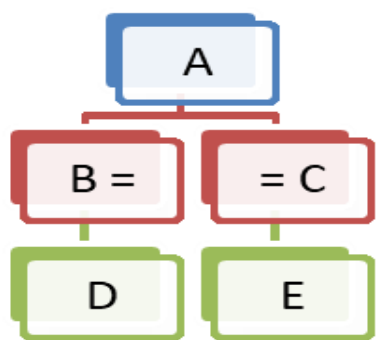

Bisa dilihat bahwasanya antara laki-laki yang berinisialkan $\mathrm{D}$ dan $\mathrm{B}$ dengan perempuan adalah merupakan anak dari si C, mereka dilirang untuk kawin dikarenakan endogami, atau sama-sama satu clan (suku). Baik B ayah dari $\mathrm{D}$, maupun $\mathrm{C}$ ayah $\mathrm{E}$, mereka menarik dari garis keturunan patrilineal kepada ayahnya si A yaitu nenek moyang dari laki-laki D dan perempuan yang berinisialkan E.

\section{Sistem Matrilinial (Garis Keibuan)}

Matrilineal adalah merupakan suatu adat istiadat masyarakat yang mengatur tentang jalur keturunan yang diambil dari garis ibu. Kata matrilineal diambil dari dua kata, yaitu mater dari bahasa latin yang mempunyai arti "ibu”, dan kata yang kedua, yaitu linea (bahasa latin) yang berarti "garis". Jadi, bisa disimpulkan bahwasanya matrilineal adalah sistem yang mengikuti garis katurunan yang ditarik dari pihak ibu sampai ke nenek moyang perempuan. ${ }^{19}$

Dalam sistem ini pihak laki-laki tidak menjadi ahli waris untuk anak-anaknya, tetapi mereka menjadi pewaris dari garis perempuan atau dari garis ibu, karena anak-anak mereka merupakan bagian dari keluarga ibunya. Sedangkan ayahnya masih merupakan anggota keluarga sendiri. ${ }^{20}$

Dengan sistem tersebut semua anak hanya dapat menjadi ahli waris dari ibunya sendiri, baik dalam pembagian harta pusaka yang tinggi maupun dalam pembagian harta pusaka yang berkategori rendah. Jika dalam

${ }^{19}$ Soerojo Wignjodipoero, Pengantar dan AsasAsas Hukum Adat (Jakarta: PT. Toko Gunung Agung, 1995), 109

${ }^{20}$ Suparman, Hukum Waris Indonesia dalam Perspektif Islam, Adat dan BW, 43. 
keluarga yang meninggal dunia itu seorang ayah, maka anak-anaknya serta isterinya tidak menjadi ahli waris untuk harta pusaka tingginya, sedangkan yang menjadi ahli warisnya adalah seluruh keponakannya.

Salah satu daerah yang masih menerapkan hukum waris adat dengan sistem matrilineal atau sistem dari garis keibuan ini adalah Minangkabau, Enggano, dan Timor. Hukum waris adat ini merupakan masalah yang aktual dalam berbagai pembahasan. Hal tersebut disebabkan karena corak dan keunikannya yang mana bila dibandingkan dengan sistem hukum kewarisan adat yang ada didaerah-daerah di Indonesia, yang man setiap orang akan selalu menghubungan dirinya kepada seorang ibu, seterusnya hingga keatas sampai pada seorang wanita yang sudah dianggap sebagai nenek moyangnya dimana gen ibunya berada dan mereka sudah menganggap satu gen (suku) yaitu dari suku ibunya.

Agar lebih dapat memahami alur dari sistem matrilineal ini perlu diperjalas dengan melihat sistem perkawinan dalam hukum adat masyarakat di Minangkabau. Berikut ada beberapa kasus perkawinan yang bisa diperhatikan sebagai berikut:

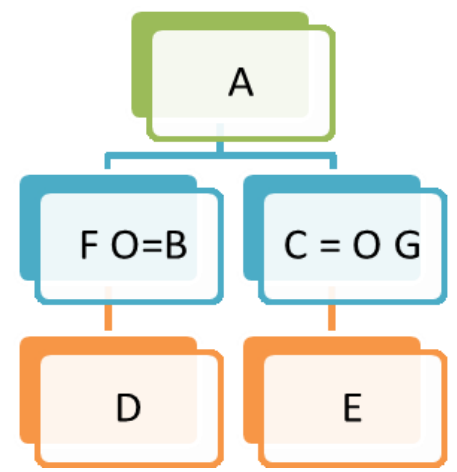

Bisa dijelaskan bahwasanya si A adalah seorang perempuan yang berasal dari suku Junaidi, ibu kandung dari perempuan B dan C, B (adalah perempuan anak A), dari perkawinannya dengan seorang pria yang berasal dari suku Aliyando bernama $\mathrm{F}$ dan melahirkan seorang anak laki-laki yang berinisial $\mathrm{D}$, sedangkan $\mathrm{C}$ (perempuan anak $\mathrm{A}$ juga), menikah dengan seorang laki-laki dari suku Koto (berinisial G), melahirkan anak perempuan yang bernama E. Bisa disimpulkan bahwasanya baik D maupun $\mathrm{E}$ walaupun ayahnya dari suku Aliyando dan Koto, akan tetapi mereka tetap menarik gars keturunan dari neneknya A (suku Junaidi). Jadi D dan E adalah merupakan satu suku, maka dilarang menikah, karena melanggar Eksogami suku.

\section{Sistem Parental Atan Bilateral (Sifat Kebapak- ibuan)}

Hukum waris parental atau bilateral ialah memberikan hak yang sama antara ahli waris laki-laki dan ahli waris perempuan, baik kepada suami maupun istri, serta anak laki-laki dan perempuan termasuk keluarga laki-laki dan keluarga perempuan. Ini menggambarkan bahwasanya anak laki-laki dan perempuan sama-sama dalam mendapatkan hak harta pusaka (warisan) yang ditinggalkan oleh kedua orangtua, bahkan seseorang yang sudah berstatus duda dan janda dalam perkembangannya juga termasuk warisan yang berasaskan timbal balik.

Sistem ini adalah peleburan antara matrilineal dan matrilineal, yaitu sistem yang ditarik dari garis keturunan bapak dan garis keturunan ibu. Maksudnya dalam pemberian antara ahli waris laki-laki dan perempuan disejajarkan secara sama untuk mendapatkan harta warisan yang ditinggalkan oleh kedua orang tua mereka.

\section{MAKNA FILOSOFIS ANAK LAKI-LAKI TERTUA SEBAGAI PENERIMA WARIS DI ADAT PEPADUN DI TIGENENENG KABUPATEN PESAWARAN}

Pada masyarakat adat Lampung yang ada di Kecamatan. Tigeneneng Kab. Pesawaran, termasuk dalam golongan masyarakat adat yang menggunakan sistem hukum adat bersifat patrilineal. Masyarakat adat patrilineal memiliki konsep dasar kekerabatan atau kekeluargaan yang berdasarkan pada garis keturunan lakilaki. Dalam masyarakat adat patrilineal 
keturunan dari bapak (laki-laki) dinilai mempunyai kedudukan yang lebih tinggi serta hak-haknya juga akan mendapatkan hak lebih banyak. Hal ini juga mempengaruhi dalam sistem kewarisan adat berupa penerusan harta waris kepada anak laki-laki, khususnya pada anak laki-laki tertua yang ditinggalkan oleh orang tuanya.

Seorang ahli waris pada anak laki-laki tertua dalam hukum adat lampung pepadun akan memegang peranan penting didalam kehidupan keluarganya dalam adat lampung pepadun diberi gelar dengan sebutan "penyeimbang". ${ }^{21}$ Sebab anak laki-laki dianggap sebagai pengganti atau penerus kepala keluarga sehingga wajib untuk bertanggung jawab penuh dalam menjaga, mengurus, dan melindungi keluarga besarnya, baik dalam hal pengurusan harta waris yang ditinggalkan maupun atas anggota keluarga yang ditinggalkan oleh pewaris.

Pada Masyarakat Adat Lampung, anak laki-laki tertua adalah ahli waris utama yang mengurus seluruh harta peninggalan orang tuanya. Dengan kewajiban mengganti kedudukan ayahnya yang sudah tua atau wafat sebagai kepala keluarga, yang bertanggung jawab mengurusi serta memelihara saudarasaudara kandungnya yang belum dewasa sampai dapat hidup mandiri. Anak laki-laki tertua yang dimaksud adalah anak laki-laki paling tua yang masih hidup saat pewaris meninggal dan mewariskan hartanya.

Pemberian hak waris terhadap anak lakilaki tertua tidak serta merta menelantarkan hak ahli waris perempuan, dikarenakan dengan memberikan harta waris kepada anak laki-laki tertua, maka semua tanggung jawabnya orang tua yang telah meninggal dunia terhadap anakanak yang telah ditinggal akan diteruskan kepadanya. Selain itu, alasan dalam pemberian

${ }^{21}$ Jalil Jalil, "Wawancara Dengan Salah Satu Anak Pepadun Dengan Gelar Adat Pangeran" (Desa Rejo Agung Kec. Tigeneneng, Kab. Pesawaran, December 21, 2018). hak waris terhadap anak tertua ini sudah berdasarkan hasil musyawarah yang telah disepakati oleh para ketua Adat. Serta dengan alasan bahwasanya dengan tidaknya memberikan harta waris kepada ahli waris dari anak perempuan, dikarenakan ketika anak perempuan dari adat pepadun ini menikah, dia akan dibawa pergi oleh suaminya serta dengan alasan bahwasanya seorang perempuan tidak bisa dan tidak pantas dijadikan sebagai ketua atau penerus dalam sebuah keluarga yang ada didalam adat lampung pepadun. ${ }^{22}$

Selain sebagai penyeimbang, pemberian hak waris terhadap anak tertua dalam tradisi Adat Lampung Pepadun adalah untuk menjaga keharmonisan dan kerukunan antar keluarga dari beberapa hal yang tidak diinginkan. Seperti halnya yang diungkapkan oleh bapak jalil, bahwasanya banyak terjadi keributan dalam hal perebutan harta waris antara ahli waris dikarenakan tidaknya sosok penyeimbang atau penerus dalam menjaga harta yang telah ditinggalkan oleh kedua orang tua yang telah meninggal dunia.

Kedudukan anak tertua dalam adat lampung pepadun dianggap mampu meneruskan tonggak yang telah ditinggalkan oleh orang tuanya (pihak ayah), karena telah disematkannya gelar si "penyeimbang" yang diberikan oleh para ketua adat dengan ritual yang begitu berat dengan menyembeli tiga sampai dengan lima ekor kerbau. Dengan kasta gelar tertinggi ini dalam keluarga inilah anak laki-laki tertua dalam adat lampung pepadun dianggap mampu dalam memegang amanah yang telah diberikan kepadanya.

\section{HAK WARIS ANAK LAKI-LAKI TERTUA DALAM HUKUM ADAT LAMPUNG PEPADUN DI TIGENENENG KABUPATEN PESAWARAN DITINJAU DARI}

22Abdul Ghani, "Wawancara Dengan Kepala Keluarga Adat Lampung Pepadun" (Bumi Agung, Kec. Tigeneneng, Kab. Pesawaran, December 15, 2018). 


\section{PERSPEKTIF GENDER}

Sistem pelaksanaan pembagian dan perhitungan harta waris dalam hukum adat lampung pepadun yang ada di Kecamatan Tigeneneng, Kab. Pesawaran adalah mutlak diberikan kepada ahli waris anak laki-laki tertua dari isteri pertama. Ketika isteri pertama tidak mempunya keturunan atau anak laki-laki maka, dalam pemberian harta warisnya bisa diberikan kepada anak laki-laki dari isteri kedua. Sedangkan untuk ahli waris dari pihak perempuan atau perempuan tidak diberikan hak kuasa dalam memegang atau mengelola harta warisan yang telah ditinggalkan oleh orang tuanya.

Alasan dengan tidak diberikan hak kuasa dalam mengelola harta waris kepada anak perempuan pada adat lampung pepadun adalah:

1. Anak perempuan dianggap tidak mampu dalam mengelola harta warisan yang telah ditinggalkan oleh kedua orang tuanya yang telah meninggal dunia;

2. Anak perempaun ketika menikah maka akan berpindah adat gelarnya dan akan mengikuti suaminya pergi;

Padahal jika melihat dari segi hukum atau aturan agama yang tertuang dalam Quran surat An-Nisa ayat 7:

Artinya: Bagi orang laki-laki ada hak bagian dari barta peninggalan ibu- bapa dan kerabatnya, dan bagi orang wanita ada hak bagian (pula) dari harta peninggalan ibu-bapa dan kerabatnya, baik sedikit atau banyake menurut bahagian yang telab ditetapkan.

Ayat diatas jelas dengan terang bahwasanya anak perempuan juga mempunyai hak dalam tirkah atau harta yang telah ditinggalkan oleh orang tuanya yang sudah meninggal dunia. Hal ini juga dipertegas dalam sabda Rasulullah SAW., yang diriwayatkan oleh Ibnu Abdillah bin Muhammad bin 'Aqil, dari Hatim bin Abdullah, dan dari Jabir r.a.

Artinya: Sesunggubnya Nabi $S A W$ memberikan kepada dua orang anak perempuan bagian dari harta warisan dua pertiga.

Namun dari urain ayat dan hadis diatas tersebut walaupun sebenarnya pihak ahli waris anak perempuan tetap mendapatkan harta warisan akan tetapi, masih dirasakannya hal yang kemudian menimbulkan ketidakadilan gender bagi anak perempuan, yaitu dalam hak kepercayaan penuh dalam memegang peranan harta waris yang hingga kini selalu diberikan kepada anak laki-laki.

Padahal dalam kenyataannya masih ada penyelewengan atau penyalah gunaan yang dilakukan oleh anak laki-laki tertua dalam menjalankan amanah yang dititipkan oleh orang tua sebagai penerus dalam pengelolaan harta waris guna menjalin kerukunan dalam keluarga. Hal inilah yang seharusnya diuriakan secara tuntas dalam menjawab dasar yang digunakan oleh para tokoh adat dalam masyarakat lampung pepadun.

Seharusnya dalam pelaksanaan yang telah dipercayakan oleh orang tua tua yang telah diberikan kepada anak laki-laki tertua sesuai dengan apa yang telah diamanatkannya. Hal ini sesuai dengan kaidah "kebijakan seorang pemimpin terhadap rakyatnya bergantung kepada kemaslahatan".

Tidak hanya menggunakan dasar adat kebiasan (urf) yang telah diturunkan secara turun menurun oleh nenek moyang dan para tokoh adat hingga saat ini yang dalam dalam realitinya masih ada ketidakadilan terutama bagi pihak perempuan sebagai ahli waris yang tertindas gendernya.

Dalam perspektif gender, praktik-praktik dalam memegang hak penuh atas harta warisan yang selama ini diberikan kepada anak laki-laki tertua, jelaslah memberikan rasa ketidakadilan bagi pihak perempuan yang notabanenya adalah ahli waris yang sama haknya. Hal ini dapat dikatakan bahwa ketentuan hukum adat sebagaimana diatas, jelas bertentangan dengan prinsip kesetaraan dan keadilan gender baik dalam Islam maupun Konvensi Internasional. Padahal secara yuridis, anak perempuan adalah 
merupakan anak yang berhak dalam memegang hak penuh dalam mengelola harta warisan yang ditinggalkan oleh orang tuanya. Namun faktanya hingga saat ini anak perempuan belum juga diberikan kepercayaan penuh dalam mengelola harta warisan. Hal ini jelas sangat bertentangan dengan prinsip kesetaraan dan keadilan gender.

Definisi gender adalah pembedaan peran anatara laki-laki dan perempuan, dimana pembedaan tersebut dibedakan karena berdasarkan konstruk budaya bukan berdasarkan kodrati. Dari berbagai definisi sebagaimana di atas, pengertian gender dapat disimpulkan bahwa gender adalah pembagian dan perbedaan peran antara laki-laki dan perempuan yang dikonstruksi secara social maupun cultural, gender berasal dari konsep hubungan social yang membedakan fungsi dan peran antara laki-laki dan perempuan, pembedaan fungsi dan peran antara laki-laki dan perempuan tersebut tidak ditentukan karena keduanya terdapat perbadaan bilogis atau kodrat, melainkan dibedakan menurut kedudukan, fungsi dan peran masing-masing dalam berbagai bidang kehidupan dan pembangunan.

Sistem atau aturan yang terdapat di dalam hukum adat Lampung Pepadun Kecatamatan Tigeneneng, Kab. Pesawaran, jika ditinjau dari persepektif keadilan gender, maka dapat dikatakan bahwa sistem hukum tersebut bertentangan karena tidak sejalan dengan nilai-nilai serta prinsip-prinsip keadilan. Dalam Islam bahwa keadilan adalah tujuan dari hukum Islam. Selain itu, sistem yang diperuntukkan khusus untuk anak perempuansaja, terkesan diskriminasi bagi perempuan. Dari konsep tersebut, terlihat bahwa, ketidakadilan yang diperoleh oleh anak perempuan karena tidak diberikannya hak untuk memegang dan mengelolaharta warisan karena dengan alasan anak perempuan tidak mampu dalam mengelola dan akan terbawa oleh suaminya.
Secara yuridis normatif kesetaraan dan keadilan gender di atur dalam Hukum Islam dan Konvensi Internasional tentang Hak-Hak Perempuan. Konsep gender dalam Islam tidak mengajarkan diskriminasi antara lelaki dan perempuan. Di hadapan Tuhan, lelaki dan perempuan mempunyai derajat yang sama. Prinsip kesetaraan gender dalam Islam, adalah: Laki-laki dan perempuan sama-sama hamba Allah. Dalam kapasitas manusia sebagai hamba Allah, tidak ada perbedaan antara laki-laki dan perempuan, keduanya mempunyai potensi dan peluang yang sama untuk menjadi hamba yang ideal. $^{23}$

Dapat ditelaah bahwa Islam diturunkan ke dunia ini adalah untuk membebaskan segenap umat manusia dari segala bentuk diskriminasi dan penindasan termasuk diskriminasi seksual, warna kulit, etnis, dan ikatan-ikata primordial lainnya. ${ }^{24}$ Allah swt. Befirman dalam QS. Al-Hujurat: 13.

Artinya: Hai manusia, sesungguhnya kami menciptakan kamu dari seorang laki-laki dan seorang perempuan dan menjadikan kamu berbangsa-bangsa dan bersuku-suku supaya kamu saling kenal mengenal. Sesunggubnya yang paling mulia di antara kamu di sisi Allah adalah orang paling bertaqwa di antara kamu. Sesunggubnya Allab Maha Mengetabui dan Maha Mengenal.

Selain perspektif Islam sebagaimana di atas, konsep kesetaraan dan keadilan gender juga ditekankan dalam konvensi internasional yakni Convention on the Elimination All Form Of Discrimination Against Women (CEDAW) atau Konvensi Penghapusan Segala Bentuk Diskriminasi terhadap Perempuan mengandung makna prinsip "kesetaraan dan non-diskriminasi” Pertama, prinsip persamaan menuju persamaan substantif yakni memandang persamaan hak lelaki dan

${ }^{23}$ Nasaruddin Umar, Perspektif Jender dalam AlQur'an, Disertasi, (Jakarta: Program Pascasarjana IAIN Syarif Hidayatullah, 1999), 244.

${ }^{24} \mathrm{M}$. Quraish Shihab, Membumikan Al-Qur'an: Fungsi dan Peran Wabyu dalam Kebudayaan Masyarakat), Cet. IV (Bandung: Mizan, t.t.), 269. 
perempuan; Kedua, prinsip non diskriminasi terutama diskriminasi berdasarkan jenis kelamin dalam pemenuhan kebebasankebebasan dasar dan hak asasi manusia. ${ }^{25}$

Aturan menegnai dua saksi yang diperoleh istri sebagaimana di atas, jelas tidak sesuai dengan ketentuan Pasal 1 Konvensi CEDAW tentang prinsip don-diskriminasi dan persamaan. Pasal 1 menjelaskan bahwa:

"diskriminasi terbadap perempuan" berarti setiap pembedaan, pengucilan atan pembatasan yang dibuat atas dasar jenis kelamin, yang mempunyai pengaruh atau tujuan untuk mengurangi atau menghapuskan pengakuan, penikmatan atau penggunaan bak-bak azasi manusia dan kebebasan-kebebasan pokok di bidang politik, ekonomi, sosial, budaya, sipil atan apapun lainnya oleh kaum perempuan, terlepas dari status perkawinan mereka, atas dasar persamaan antara laki-laki dan perempuan".

Hal inilah yang ditekankan dalam Konvensi CEDAW yaitu prinsip persamaan dan keadilan merupakan sebuah keharusan. Keharusan karena prinsip keadilan serta kesetaraan antara laki-laki dan perempuan merupakan sebuah perwujudan HAM yang dimiliki oleh semua umat, khususnya kaum perempuan. Kenapa konsep HAM itu sesuatu yang sangat penting dalam kenegaraan Indonesia, karena Indonesia telah memploklamirkan sebagai konsep negara hukum. ${ }^{26}$ Ciri dari negara hukum diantaranya adalah adanya jaminan terhadap perlindungan HAM serta menjunjung tinggi prinsip persamaan dan keadilan.

Prinsip persamaan dan keadilan khuusnya dalam hukum "equality before the Law"

${ }^{25}$ Achie Sudiarti Luhulima, "Efektivitas Pelaksanaan Konvensi Penghapusan Segala Bentuk Diskriminasi terhadap Perempuan: Jaminan bagi Realisasi Hak-hak Perempuan", dalam http:/ /www.cedawui.org, diakses tanggal 17-11-16, 1.

26 Udiyo Basuki, "Perlindungan HAM dalam Negara Hukum Indonesia: Studi Ratifikasi Konvensi Hak-hak Disabilitas (Convention on The Rights of Persons with Disabilities)" Jurnal SOSIO-RELIGIA, Vol. 10, No.1, Februari-Juni 2012, 23-24. ini terkandung di dalam UUD 45 Pasal 28B ayat (1) dan (2) serta Pasal 28D ayat (1) yang berbunyi: "Setiap orang berbak atas pengakuan, jaminan, perlindungan, dan kepastian bukum yang adil serta perlakuan yang sama dibadapan bukum". Hal ini tentu sejalan dengan asas-asas negara hukum yang meliputi 5 (lima) hal, salah satu diantaranya adalah prinsip persamaan dihadapan hukum (equality before the Law) prinsip ini dalam negara hukum bermakna bahwa pemerintah tidak boleh mengistimewakan orang atau kelompok orang tertentu, atau memdiskriminasikan orang atau kelompok orang tertentu.

Di dalam prinsip ini, terkandung (a) adanya jaminan persamaan bagi semua orang di hadapan hukum dan pemerintahan, dan (b) tersedianya mekanisme untuk menuntut perlakuan yang sama bagi semua warga negara. Dengan demikian hukum atau perundangundangan harus memberi perlindungan dan kepastian hukum yang adil khususnya terhadap perempuan.

Dari analisis sebagaimana di atas, dapat disimpulkan bahwa, pemberian hak dalam menerima dan mengelola yang selama ini berikan kepada ahli waris perempuan dengan mengecualikan ahli waris peempuan bertentangan dengan prinsip-prinsip keadilan dan kesetaraan gender baik dalam Islam, Konvensi Internasional (CEDAW) dan UUD 1945.

Praktik-praktik yang mendiskriminasikan perempuan dalam masyarakat sosial adat, khususnya dengan tidak memberikan hak dalam menerima dan mengelola harta warisan secara adat sangat jelas budaya dan ideologi bukan satu hal yang diajarkan oleh Tuhan. Ia dibentuk oleh manusia dan disosialisasikan dari satu generasi ke generasi berikutnya. Nilai budaya adalah faktor mental yang menentukan perbuatan seseorang atau masyarakat. Dalam budaya Indonesia, seperti juga di banyak negara dunia ketiga lainnya, budaya patriarki masih sangat kental. Dalam kehidupan sosial, 
politik, ekonomi, dan terlebih lagi dalam budaya, keadaan ketimpangan, asimetris, dan sub ordinatif terhadap perempuan tampak sangat jelas. Dalam kondisi yang seperti itu, proses marjinalisasi terhadap perempuan terjadi pada gilirannya perempuan kehilangan otonomi atas dirinya. Eksploitasi serta kekerasan terjadi terhadap perempuan, baik di wilayah domestik, maupun publik. Dalam situasi demikian, maka perbedaan, diskriminasi, dan ketidakadilan gender tumbuh dengan suburnya. Meskipun secara formal, dalam UUD 1945, hak laki-laki dan perempuan tidak dibedakan, tetapi dalam kenyataannya sangat berbeda.

\section{KESIMPULAN}

Dari beberapa uraian diatas maka, penelitian ini dapat disimpulkan bahwa pada masyarakat adat Lampung yang ada di Kecamatan. Tigeneneng Kab. Pesawaran, termasuk dalam golongan masyarakat adat yang menggunakan sistem hukum adat bersifat patrilineal.Seorang ahli waris pada anak laki-laki tertuadalam hukum adat lampung pepadun akan memegang peranan penting didalam kehidupan keluarganya dalam adat lampung pepadun diberi gelar dengan sebutan "penyeimbang".Sebab anak laki-laki dianggap sebagai pengganti atau penerus kepala keluarga sehingga wajib untuk bertanggung jawab penuh dalam menjaga, mengurus, dan melindungi keluarga besarnya, baik dalam hal pengurusan harta waris yang ditinggalkan maupun atas anggota keluarga yang ditinggalkan oleh pewaris.

Sistem pelaksanaan pembagian dan perhitungan harta waris dalam hukum adat lampung pepadun yang ada di Kecamatan Tigeneneng, Kab. Pesawaran adalah mutlak diberikan kepada ahli waris anak laki-laki tertua dari isteri pertama. Ketika isteri pertama tidak mempunya keturunan atau anak laki-laki maka, dalam pemberian harta warisnya bisa diberikan kepada anak laki-laki dari isteri kedua.
Sedangkan untuk ahli waris dari pihak perempuan atau perempuan tidak diberikan hak kuasa dalam memegang atau mengelola harta warisan yang telah ditinggalkan oleh orang tuanya.

Alasan dengan tidak diberikan hak kuasa dalam mengelola harta waris kepada anak perempuan pada adat lampung pepadun adalah: a) Anak perempuan dianggap tidak mampu dalam mengelola harta warisan yang telah ditinggalkan oleh kedua orang tuanya yang telah meninggal dunia, b) Anak perempaun ketika menikah maka akan berpindah adat gelarnya dan akan mengikuti suaminya pergi.

Hal ini jelas sangat bertentangan dengan prinsip kesetaraan dan keadilan gender. Secara yuridis normatifkesetaraan dan keadilan gender telah diatur dalam Hukum Islam dan Konvensi Internasional. Padahal secara yuridis, anak perempuan adalah mempunyai hak yang sama dalam mengelola harta warisan. Namun faktanya ketika orang tua meninggal dunia maka, harta warisan mutlak diserahkan kepada anak laki-laki tertua. Secara yuridis normative kesetaraan dan keadilan gender di atur dalam Hukum Islam dan Konvensi Internasional tentang Hak-Hak Perempuan. Konsep gender dalam Islam tidak mengajarkan diskriminasi antara lelaki dan perempuan. Di hadapan Tuhan, lelaki dan perempuan mempunyai derajat yang sama. Prinsip kesetaraan gender dalam Islam, adalah: Laki-laki dan perempuan sama-sama hamba Allah. Dalam kapasitas manusia sebagai hamba Allah, tidak ada perbedaan antara laki-laki dan perempuan, keduanya mempunyai potensi dan peranan yang sama untuk menjadi hamba yang ideal. 


\section{DAFTAR KEPUSTAKAAN}

Asri Thaher. "Sistem Pewarisan Kekerabatan Matrilineal Dan Perkembangannya Di Kecamatan Banuhampu Pemerintahan Kota Agam Propinsi Sumatera Barat." PhD Thesis, Universitas Diponegoro, 2006.

Astuti MR, Juli. "Kedudukan Anak Luar Kawin Dalam Pewarisan Adat Di Kecamatan Colomadu Kabupaten Karanganyar.” PhD Thesis, Universitas Diponegoro, 2004.

Departemen Agama RI. Al-Qur'an Dan Terjemabnya. Bandung: CV. J-ART, 2005.

Fikri \& Wahidin, Fikri \& Wahidin. "Konsepsi Hukum Waris Islam dan Hukum Waris Adat (Analisis Kontekstualisasi dalam Masyarakat Bugis)." Al-Abkam: Jurnal Ilmu Syariah dan Hukum 2, no. 2 (January 8, 2017). doi:10.22515/al-ahkam.v2i2.500.

Ghani, Abdul. "Wawancara Dengan Kepala Keluarga Adat Lampung Pepadun.” Bumi Agung, Kec. Tigeneneng, Kab. Pesawaran, December 15, 2018.

Hadikusuma, Hilman. Hukum Waris Adat. Bandung: Citra Aditya Bakti, 1990.

- Pengantar Ilmu Hukum Adat Indonesia. Bandung: Mandar Maju, 1992.

Jalil, Jalil. "Wawancara Dengan Salah Satu Anak Pepadun Dengan Gelar Adat Pangeran.” Desa Rejo Agung Kec. Tigeneneng, Kab. Pesawaran, December 21, 2018.

Jamaa, La. "Dimensi Ilahi dan Dimensi Insani dalam Maqashid al-Syari'ah" 45 (2011): 20.

Komari. "Eksistensi Hukum Waris Di Indonesia: Antara Adat Dan Syariat." Asy-Syari'ab 17, no. 2 (August 2015): 158-72.

M. Syifa'uddin, Achmadi. Pintar Imu Faraidl Pilihan Tepat Meredam Sengketa Harta Waris. Cet. 1. Surabaya: Khalista, 2006.

Mukhlishin, A, Nur Alfi Khotamin, Ari Rohmawati, and Ariyanto Ariyanto. "Studi Hukum Islam Terhadap Kewarisan Masyarakat Adat Semendo Kabupaten Lampung Barat Di Era Kontemporer." ULUL ALBAB Jurnal Studi Islam 18, no. 1 (July 31, 2017): 84. doi:10.18860/ua.v18i1.4125.

Rusyd, Ibnu. Bidayatul Mujtahid Analisis Fiqih Para Mujtahid. Jilid. 3, Cet. III. Jakarta: Pustaka Amani, 2007.

Saebani, Beni Ahmad. Figh Mawaris. Cet. 1. Bandung: CV. Pustaka Setia, 2009.

- Fiqh Mawaris. Cet.3. Bandung: CV. Pustaka Setia, 2015.

Sakirman. "Konvergensi Pembagian Harta Waris Dalam Hukum Islam." ALHURRIY AH: Jurnal Hukum Islam 2, no. 1 (July 18, 2017): 45-56-56. doi:10.30983/alhurriyah.v2i1.261.

Shihab, M. Quraish. Membumikan AL-Qur'an: Fungsi Dan Peran Wabyu Dalam Kebudayaan Masyarakat ). Cet. IV. Bandung: Mizan, n.d.

Soekamto, Soejono. Pengantar Hukum Adat Indonesia. Jakarta: Rajawali, 1993.

Suparman, Eman. Hukum Waris Indonesia Dalam Perspektif Islam, Adat Dan BW. Jakarta: Refika Aditama, 2005.

Umar, Nasaruddin. Perspektif Jender Dalam Al-Qur'an, Disertasi,. Jakarta: Program Pascasarjana IAIN Syarif Hidayatullah, 1999.

Wignjodipoero, Soerojo. Pengantar Dan Asas-Asas Hukum Adat. Jakarta: PT. Toko Gunung Agung, 1995. 